\title{
Persepsi Mahasiswa Sekolah Tinggi Pariwisata terhadap Pembelajaran Bahasa Arab
}

\author{
Afjalurrahmansyah \\ Sekolah Tinggi Pariwisata (STIPAR) Soromandi Bima, Nusa Tenggara Barat \\ E-mail:afjalelfarisy@gmail.com
}

\begin{abstract}
Article Info
Article History

Received: 2021-03-12

Revised: 2021-04-20

Published: 2021-06-02

\section{Abstract}

This study analyzes in qualitative descriptively of the Student's perception of Learning Arabic language of the Tourism Program Study at the Tourism College of Soromand Bima. The method used in this study was qualitative description by using survey techniques of questionnair.The population of this study was Tourism College of Soromandi Bima from the students of Tourism Program Study in academic year 2019,

Keywords:

Perception;

College student;

Learning;

Arabic. the number of students is consists of 66 (sixty-six) students and used total sampling techniques. Primary data were analyze using by a descriptive statistical approach to determine the frequency of the student answer and precentage. Perceptions indicator on the questionnair are based on Walgito's theory, namely; Absorption, Understanding, and Assessment or evaluation.The result of this study showed that the students's perceptionin learning Arabic were still low, which had an implications on the low of the students competence in learning Arabic language. Intrinsic motivation and extrinsic support are needed to boots student's language compentece.
\end{abstract}

\begin{tabular}{l}
\hline Artikel Info \\
\hline Sejarah Artikel \\
Diterima: 2021-03-12 \\
Direvisi: 2021-04-20 \\
Dipublikasi: 2021-06-02
\end{tabular}

Kata kunci:

Persepsi;

Mahasiswa;

Pembelajaran;

Bahasa Arab.

\begin{abstract}
Abstrak
Penelitian ini mengkaji secara deskriptif kuantitatif tentang persepsi mahasiswa program studi Pariwisata Sekolah Tinggi Pariwisata Soromandi Bima terhadap pembelajaran bahasa Arab. Metode penelitian yang digunakan adalah deskriptif kuantitatif dengan menggunakan tekhnik survei (kuesioner). Populasi pada penelitian ini adalah mahasiswa program studi Pariwisata angkatan 2019 yang berjumlah 66 orang dan menggunakan tekhnik pengambilan total sampling. Data primer dianalisis menggunakan pendekatan statistik deskriptif untuk mengetahui frekuensi jawaban dan persentasenya. Indikator persepsi pada kuesioner berdasarkan pada teori Walgito yaitu penyerapan, pengertian dan penilaian atau evaluasi. Hasil penelitian menunjukkan bahwa persepsi mahasiswa terhadap pembelajaran bahasa Arab tergolong rendah, yang berimplikasi pada rendahnya kompetensi berbahasa mahasiswa. Dibutuhkan motivasi intrinsik dan dukungan ekstrinsik untuk mendongkrak kompetensi berbahasa mahasiswa.
\end{abstract}

\section{PENDAHULUAN}

Era globalisasi dan industrialisasi menuntut setiap insan yang ingin terus survive dan eksis dalam kehidupan untuk terampil dalam berbahasa asing. Penguasaan ilmu pengetahuan, wawasan dan profesionalitas kerja di bidang tertentu saja tidaklah cukup pada era ini, melainkan perlu dan wajib dibekali dengan kemampuan berkomunikasi dalam bahasa asing secara aktif. Salah satu bahasa asing yang menjadi bahasa mayor di dunia diantaranya adalah bahasa Arab, Bahasa Arab merupakan bahasa yang paling banyak menyandang atribut. Selain sebagai bahasa agama dan umat Islam yang dimana kitab suci Al-Qur'an dan Hadis Nabi Muhammad Saw berbahasa Arab, juga menjadi bahasa resmi di PBB, bahasa yang secara resmi digunakan oleh 22 negara di kawasan Timur Tengah dan bahasa warisan sosial budaya (lughat at-turats). Bahkan menurut Wafa Kamil (2006: 6) bahasa Arab dari segi jumlah native speaker-nya menempati urutan kelima dari 20 bahasa dunia. Sedangkan dari segi penggunanya sebagai bahasa resmi (lughah rassmiyyah) bahasa Arab menempati posisi ketujuh (digunakan lebih dari 170 juta orang). Sementara itu, dari segi jumlah negara yang menetapkan bahasa Arab sebagai bahasa resmi, bahasa Arab menduduki peringkat ketiga setelah bahasa Inggris dan bahasa Spanyol (Ridlo, 2015: 214). Bahkan akhir-akhir ini menjadi bahasa yang peminatnya cukup besar di Barat. Di Amerika, misalnya, hampir tidak ada suatu perguruan tinggi yang tidak menjadikan bahasa Arab sebagai salah satu mata kuliah termasuk di perguruan tinggi Katholik atau Kristen. Bahkan di Harvard University dan Georgetown University mempunyai pusat studi Arab yang kurang lebih merupakan Center for Contemporary Arab Studies (Arsyad, 2010: 1).

Di Indonesia sendiri, bahasa Arab bukanlah suatu bahasa yang asing, jauh sebelum Indonesia menggapai 
kemerdekaannya, bangsa-bangsa asing terutama bangsa Arab sudah masuk ke Indonesia. Bahasa Arab kemudian lahir dari kaki tangan para pedagang, musafir, mubalig Arab, Persia dan India, serta menjadikan bahasa Arab sebagai alat komunikasi dengan penduduk lokal (Nusantara) yang menggunakan bahasa yang berbeda-beda untuk melakukan suatu transaksi saat itu (Azra, 2007: 43). Dan mulai berkembang di bumi Nusantara sekitar abad ke-11 hingga ke-12 M (Hadi, 1995: 235). Bahasa Arab memiliki banyak keistimewaan dibanding bahasa-bahasa lain, karena selain sebagai bahasa komunikasi antar masyarakat dan bangsa, sebagai bahasa sosial, politik dan ekonomi, bahasa Arab juga merupakan bahasa kitab suci dan tuntunan agama Islam sedunia. Sehingga tidaklah heran jika bahasa Arab sudah begitu dekat dengan masyarakat Indonesia.

Bahasa Arab selain sebagai wasilah untuk lebih memahami dan mendalami ajaran agama Islam dari kitab-kitab primer seperti Al-Qur'an, Hadis maupun kutubut turats, dalam perkembangannya juga telah menjadi wasilah penting dalam memahami ilmu pengetahuan berupa sains, sosial budaya, hingga kerjasama ekonomi internasional antara Indonesia dan negara-negara Arab (Tohe, 2018; Sauri, 2020). Pada perkembangannya, derasnya arus globalisasi juga membawa dampak positif pada perkembangan bahasa Arab di Indonesia, khususnya pada sektor pariwisata. Sektor pariwisata yang telah berperan sebagai penyumbang devisa terbesar kedua setelah migas, menjadi industri atau sektor penting yang dapat di andalkan pemerintah kedepan untuk menjadi pilar utama pembangunan ekonomi (Rodjinandri dan Supriadi, 2016: 73). Tentunya untuk menopang dan terus mendukung perkembangan pariwisata di Indonesia khususnya di Nusa Tenggara Barat diperlukan pengajaran bahasa asing salah satunya adalah bahasa Arab yang bisa difungsikan untuk memasifkan promosi dan pelayanan wisata di daerah tersebut.

Semenjak tahun 2012 Indonesia telah mencanangkan pariwisata halal untuk mengakomodir minat wisatawan asing yang berasal dari negaranegara Islam. Bahkan pariwisata halal menjadi branding bagi pengembangan industri pariwisata Lombok NTB sehingga bisa menjadi tujuan wisata alternatif (Nasarudin, 2018). Melihat perkembangan sektor pariwisata di Indonesia, khususnya pariwisata halal, maka perlu diimbangi dengan kualitas dan kompetensi SDM yang aktif berbahasa Arab dan memiliki pengetahuan kepariwisataan.

Keterampilan berkomunikasi aktif menggunakan bahasa Arab bagi mahasiswa memiliki manfaat yang sangat banyak, baik untuk pengembangan keilmuannya, komunikasi sosial, politik, ekonomi, budaya bahkan pada tataran kehidupannya seharihari. Bila dikaitkan dengan prospek kerja lulusan pariwisata maka bahasa Arab berguna bagi mereka yang ingin mengabdi pada pelayanan reservasi, pelayanan akomodasi (hotel atau perjalanan), pemandu wisata, alat komunikasi dan lain-lain.

Oleh karena itu, salah satu sekolah tinggi pariwisata di NTB yakni Sekolah Tinggi Pariwisata (STIPAR) Soromandi Bima menjadikan bahasa Arab sebagai salah satu mata kuliah yang wajib dipelajari oleh mahasiswa-mahasiswa yang menempuh pendidikan di perguruan tinggi tersebut. Mengingat bahasa Arab dapat menjadi salah satu sarana yang dapat mensukseskan seseorang di bidang akademik dan di dunia kerja (Megawati; 2016).

Keistimewaan dan prospek yang menjanjikan terhadap kemahiran berbahasa Arab tersebut tidak serta merta menjadikan mahasiswa antusias dan penuh gairah dalam mendalami bahasa Arab. Citra kurang positif sebagai bahasa yang sulit dipelajari nampaknya masih melekat padanya. Sehingga realitanya masih ditemukan fenomena rendahnya penguasaan bahasa Arab mahasiswa, motivasi dan semangat mereka yang masih rendah, ditemukan berbagai keluh kesah mahasiswa terkait kesulitan yang mereka hadapi dalam pembelajaran bahasa Arab termasuk kompleksitas gramatikal bahasa Arab yang membingungkan jika dibandingkan dengan bahasa internasional lainnya.

Problematika yang dihadapi oleh mahasiswa berdasarkan observasi awal yang dilakukan antara lain lemahnya pengetahuan dasar, intensitas interaksi dengan bahasa Arab yang minim, bahan bacaan yang kurang, kesulitan pada pengucapan dan problemproblem lainnya. Disamping bahasa Arab yang memiliki kompleksitas yang tinggi baik secara morfologi, sintaksis, semantic dan leksikal (Muhajir, 2018: 89).

Problematika pembelajaran yang dialami oleh mahasiswa tentunya menjadi atensi khusus buat pengajar dan bukanlah suatu halangan melainkan tantangan yang perlu dicarikan solusi penyelesaiannya, Maka Penelitian ini berusaha untuk menganilisa dan menelusuri persepsi mahasiswa terhadap pembelajaran bahasa Arab. Persepsi secara etimologis berasal dari kata perception (Inggris) dan percipare (bahasa latin) yang berarti menerima atau mengambil (Sobur, 2003: 445). Persepsi dari perspektif psikologi mengandung arti proses yang berkaitan dengan masuknya pesan atau informasi ke dalam otak manusia, melalui persepsi ini manusia terus menerus mengadakan interaksi atau hubungan dengan lingkungannya. Hubungan ini dilakukan lewat indra penglihatan, pendengaran, peraba, perasa dan penciuman (Slameto, 2010: 102). Sedangkan menurut Suharman persepsi merupakan suatu proses menginterpretasikan atau menafsirkan informasi yang diperoleh melalui sistem alat indera manusia (Suharman, 2005: 23). Dengan demikian persepsi bisa diartikan cara dan bagaimana seseorang melihat, memandang dan menginterpretasikan sesuatu berdasarkan alat indra yang dimilikinya. Penelitian ini diharapkan dapat bermanfaat bagi banyak pihak baik yang terlibat pada proses pembelajaran, dosen dan mahasiswa maupun pengambil kebijakan di lingkup institusi dan pemerintah setempat. 


\section{METODE PENELITIAN}

Penelitian ini menggunakan metode deskriptif kuantitatif dengan teknik survei untuk memperoleh deskripsi atau gambaran rinci tentang persepsi mahasiswa terhadap pembelajaran bahasa Arab. Responden pada penelitian ini adalah mahasiswa program studi pariwisata Sekolah Tinggi Pariwisata (STIPAR) Soromandi Bima angkatan 2019 yang berjumlah 66 orang yang sekaligus menjadi populasi pada penelitian ini. Jumlah populasi tersebut semuanya dijadikan sebagai sampel dengan tekhnik total sampling, sesuai dengan tekhnik yang digunakan. Tekhnik pengumpulan data menggunakan kuesioner. Data yang terkumpul diolah menggunakan komputer program SPSS for Window, dianalisis dengan pendekatan statistik deskriptif untuk mengetahui frekuensi jawaban responden dan persentase serta interpretasinya. Kuesioner yang digunakan adalah kuesioner tertutup yang berisi pernyataan sekitar pembelajaran bahasa Arab. Kuesioner berisi lima alternatif jawaban yaitu : Sangat Setuju (SS), Setuju (S), Ragu-Ragu (RR), Tidak Setuju (TS) dan Sangat Tidak Setuju (STS). Untuk kepentingan analisis setiap alternatif jawaban diberi bobot berjenjang mulai dari $5,4,3,2$, 1. Indikator persepsi pada kuesioner berdasarkan pada teori Walgito $(1990 ; 54)$ yang berkaitan dengaan "penyerapan, pengertian dan penilaian atau evaluasi".

\section{HASIL DAN PEMBAHASAN}

\section{A. Hasil Penelitian}

Berdasarkan hasil dari penyebaran kuesioner terhadap 66 responden mahasiswa terkait pembelajaran bahasa Arab di STIPAR Soromandi Bima, maka diperoleh rekapitulasi data sebagai berikut :

Tabel 1. Rekapitulasi Jawaban Responden

\begin{tabular}{ccc}
\hline AJ & $\begin{array}{c}\text { Jumlah Butir } \\
\text { Kuisioner }\end{array}$ & Porsentase (\%) \\
\hline SS & 130 & $19,69 \%$ \\
\hline S & 154 & $23,33 \%$ \\
\hline RR & 103 & $15,60 \%$ \\
\hline TS & 210 & $31,81 \%$ \\
\hline STS & 63 & $09,54 \%$ \\
\hline & $\mathbf{6 6 0}$ & $\mathbf{1 0 0 \%}$ \\
\hline
\end{tabular}

Data yang tertera pada tabel di atas, berdasarkan jawaban atas kuesioner yang telah disebarkan kepada 66 mahasiswa program studi Pariwisata STIPAR Soromandi Bima angkatan 2019. Pada data tersebut terlihat bahwa setiap responden secara keseluruhan memberikan jawaban yang variatif terhadap alternatif jawaban yang telah disediakan pada kuesioner. Berdasarkan karakter persepsi bahwa penyerapan, pengertian dan penilaian atau evaluasi setiap orang akan berbeda atas objek yang sama. Secara detailnya bahwa frekuensi persentase jawaban Sangat Setuju (SS) sebanyak 130 (19,69\%), Setuju
(S) sebanyak 154 (23,33\%), Ragu-Ragu (RR) sebanyak 103 (15,60\%), Tidak Setuju (TS) sebanyak 210 (31,81\%) dan Sangat Tidak Setuju (STS) sebanyak $63(09,54 \%)$. Dan frekuensi persentase alternatif jawaban paling banyak adalah Tidak Setuju (TS) yakni sebesar 210 atau $31,81 \%$ dan paling rendah ada pada alternatif jawaban Sangat Tidak Setuju (STS) yakni sebesar 63 atau $09,54 \%$.

\section{B. Pembahasan}

Berdasarkan hasil penelitian terhadap persepsi mahasiswa program studi Pariwisata STIPAR Soromandi Bima angkatan 2019 terhadap pembelajaran bahasa Arab, melalui sebaran kuesioner yang disebarkan kepada 66 responden (mahasiswa) dengan lima alternatif jawaban, didapatkan hasil bahwa alternatif jawaban yang paling banyak dipilih oleh para responden adalah Tidak Setuju yakni sebesar 210 (31,81\%). Data tersebut memiliki relevansi dengan hasil analisis deskriptif yang secara umum menunjukkan persepsi mahasiswa berada pada interval rendah. Hasil penelitian ini menunjukkan bahwa rendahnya persepsi mahasiswa terhadap pembelajaran bahasa Arab yang didukung oleh fakta penelitian sehingga fenomena yang terjadi bukanlah semata dugaan atau asumsi.

Berikut akan diuraikan secara spesifik berkaitan dengan rendahnya persepsi mahasiswa terhadap pembelajaran bahasa Arab berdasarkan butiran kuesioner yang berjumlah sepuluh butir.

Butir kuesioner pertama tentang penguasaan bahasa Arab dan prospeknya untuk kepentingan kerja. Dari 66 responden, 50 mahasiswa $(75,75 \%)$ menjawab sangat setuju, dan 14 responden $(24,24 \%)$ menjawab setuju, 2 responden $(03,03 \%)$ menjawab ragu-ragu dan $0 \%$ responden yang menjawab tidak setuju dan sangat tidak setuju.. Data ini menunjukkan bahwa persepsi mahasiswa tentang pentingnya penguasaan bahasa Arab dan prospek kerja kedepannya sangat baik. Setidaknya itu menjadi motivasi tersendiri bagi mereka untuk belajar bahasa Arab, melihat geliat perkembangan sektor pariwisata yang tentunya akan semakin meningkatkannya jumlah wisatawan dan berdampak positif untuk para pekerja dibidang wisata.

Butir kedua, tentang motivasi dan semangat mahasiswa ketika mata kuliah bahasa Arab diajarkan. Berdasarkan data menunjukan bahwa 13 responden $(19,69 \%)$ menjawab sangat setuju, 10 responden $(15,15 \%)$ menjawab setuju, 17 responden $(25,75 \%)$ menjawab ragu-ragu, 24 responden $(36,36 \%)$ menjawab tidak setuju dan 2 responden $(03,03 \%)$ menjawab sangat tidak setuju. Dengan demikian persepsi semangat mahasiswa ketika pembelajaran bahasa Arab masih dalam kategori rendah jika dilihat dari 
persentasi jawaban mahasiswa yang tidak setuju dan sangat tidak setuju.

Butir kuesioner ketiga berkaitan dengan persepsi mahasiswa terkait tugas kuliah bahasa Arab yang dibebankan kepada mereka apakah biasa saja, wajar, atau tidak terlalu berat. Data menunjukkan bahwa persepsi mahasiswa terkait hal tersebut masih dalam kategori wajar, hal tersebut terlihat dari persentasi jawaban mahasiswa terhadap kuesioner yang dibagikan dimana sebesar $48,48 \%$ (32 responden) menjawab setuju, $12,12 \% \quad$ (8 responden) menjawab sangat setuju, sedangkan sisanya $07,57 \%$ (5 responden) menjawab ragu-ragu, 22,72\% (15 responden) menjawab tidak setuju dan $09,09 \%$ (6 responden) menjawab sangat tidak setuju.

Kuesioner keempat, berkaitan dengan persepsi mahasiswa bahwa mata kuliah bahasa Arab mudah atau sama dengan mata kuliah lainnya. Hasil kuesioner menunjukkan bahwa dari 66 responden, 3 responden $(04,54 \%)$ menjawab sangat setuju, 7 responden $(10,60 \%)$ menjawab setuju, 15 responden $(22,72 \%)$ menjawab ragu-ragu, 25 responden $(37,87 \%)$ menjawab tidak setuju dan 16 responden $(24,24 \%)$ menjawab sangat tidak setuju. Hasil tersebut mengindikasikan bahwa mata kuliah bahasa Arab dikategorikan sebagai salah satu mata kuliah yang cukup sulit bagi mahasiswa. Hal tersebut tidak terlepas dari kompleksitas gramatikal bahasa Arab bila dibandingkan dengan bahasa lainnya.

Butir kuesioner kelima tentang kesan mahasiswa dalam belajar bahasa Arab cukup bergengsi dan prestisius. Data hasil kuesioner menunjukkan bahwa 11 orang responden $(16,66 \%)$ menjawab sangat setuju, 38 responden (57,57\%) menjawab setuju, 9 responden $(13,63 \%)$ menjawab ragu-ragu, 6 responden (09,09\%) menjawab tidak setuju dan 2 responden $(03,03 \%)$ responden menjawab sangat tidak setuju. Hasil tersebut menunjukkan bahwa bahasa Arab termasuk mata kuliah yang bergengsi dan prestisius bagi mahasiswa, dilihat dari $57,57 \%$ responden yang manjawab setuju. Meskipun tidak berbanding lurus dengan semangatnya dalam mempelajari bahasa Arab.

Butir kuesioner keenam tentang lingkungan akademik kampus sangat mendukung pembelajaran bahasa Arab. Dari 66 responden tidak ada seorangpun (0\%) menjawab sangat setuju, hanya 2 responden $(03,03 \%)$ yang menjawab setuju. 23 responden $(34,84 \%)$ menjawab ragu-ragu. 30 responden $(45,45 \%)$ menjawab tidak setuju dan 11 responden $(16,66 \%)$ menjawab sangat tidak setuju. Jawaban tidak setuju menjadi jawaban responden terbanyak yakni $45,45 \%$ yang menunjukkan bahwa dukungan dari lingkungan akademik kampus sangat kurang. Hal tersebut tidak mengherankan karena tidak adanya bi'ah lughah yang di harapkan mampu mendongkrak kompetensi bahasa Arab mahasiswa di lingkungan kampus.

Butir kuesioner ketujuh, tentang tersedianya fasilitas yang memadai sebagai penunjang pembelajaran bahasa Arab, seperti laboratorium bahasa, multimedia dan lain-lain. Dari 66 responden tidak ada seorang respondenpun $(0 \%)$ yang menjawab sangat setuju dan setuju. 6 responden $(09,09 \%)$ menjawab ragu-ragu. 55 responden $(83,33 \%)$ menjawab tidak setuju dan 5 responden $(07,57 \%)$ menjawab sangat tidak setuju. Hasil dari data tersebut tidaklah mengherankan mengingat kampus STIPAR Soromandi Bima masihlah baru, sehingga sarana penunjang seperti laboratorium, multimedia dan lain-lain belum tersedia.

Butir kuesioner kedelapan, tentang kemudahan metode dan strategi pembelajaran bahasa Arab yang diterapkan oleh dosen pada proses pembelajaran bahasa Arab. Dari 66 responden,13 responden $(19,69 \%)$ menjawab sangat setuju, 25 responden $(37,87 \%)$ menjawab setuju, 11 responden $(16,66 \%)$ menjawab ragu-ragu, 13 responden $(19,69 \%)$ menjawab tidak setuju dan 4 responden $(06,06 \%)$ menjawab sangat tidak setuju. Dari hasil kuesioner tersebut menunjukkan bahwa metode dan strategi yang diterapkan oleh dosen termasuk kategori mudah dengan persentase 37,87\% menjawab setuju dan 19,69\% menjawab sangat setuju. Meskipun demikian semangat mahasiswa masih berbanding terbalik dengan kemudahan metode yang diterapkan oleh dosen. Hal tersebut terlihat dari butir angket kedua yang menunjukkan semangat belajar bahasa Arab mahasiswa masih rendah.

Butir kuesioner kesembilan tentang tidak semua keterampilan berbahasa yang meliputi keterampilan mendengarkan, berbicara, membaca dan menulis harus dikuasai oleh mahasiswa. Hasil kuesioner menunjukkan sebanyak 19 responden $(28,78 \%)$ menjawab sangat setuju, 15 responden $(22,72 \%)$ menjawab setuju, 9 responden $(13,63 \%)$ menjawab ragu-ragu, 17 responden $(25,75 \%)$ menjawab tidak setuju dan sisanya 6 responden (09,09\%) menjawab sangat tidak setuju. Jawaban terbanyak berdasarkan hasil kuesioner tersebut adalah sebesar 28,78\% mahasiswa menjawab sangat setuju, artinya mahasiswa menganggap bahwa tidak semua keterampilan berbahasa perlu mereka kuasai. Keterampilan mendengarkan dan berbicara menjadi modal utama bagi mereka untuk kebutuhan dunia kerja, khususnya di bidang pariwisata.

Butir kuesioner kesepuluh tentang jumlah SKS untuk mata kuliah bahasa Arab sudah memadai dan cukup untuk meningkapkan kompetensi berbahasa mahasiswa. Hasil kuesioner menunjukkan 13 responden (19,69\%) menjawab sangat setuju, 11 responden $(16,66 \%)$ menjawab setuju, 6 responden $(09,09 \%)$ menjawab ragu- 
ragu, 25 responden $(37,87 \%)$ menjawab tidak setuju dan 11 responden (16,66\%) menjawab sangat tidak setuju. Hasil kuesioner menunjukkan bahwa mayoritas responden menganggap jumlah SKS untuk bahasa Arab masih belum cukup dan memadai untuk peningkatan kompetensi berbahasa Arab mereka dengan persentase $37,87 \%$ yang menjawab tidak setuju dan $16,66 \%$ yang menjawab sangat tidak setuju.

Berdasarkan pemaparan hasil dari setiap butir kuesioner tersebut menunjukkan bahwa persepsi mahasiswa program studi Pariwisata pada STIPAR Soromandi Bima masih rendah. Rendahnya persepsi tersebut antara lain disebabkan oleh rendahnya minat, minimnya kemampuan dasar, lingkungan yang kurang mendukung dan kompleksitas bahasa Arab itu sendiri. Yang secara umum dapat disimpulkan bahwa semangat dan motivasi intrinsik mahasiswa masih rendah ditambah lagi dorongan dan dukungan ekstrinsik masih minim. Persepsi mahasiswa yang masih rendah tersebut menjadi pekerjaan rumah tersendiri bagi dosen pengampu dan pengambil kebijakan di lingkup perguruan tinggi sehingga persepsi mahasiswa meningkat yang akhirnya dapat meningkatkan kompetensi mahasiswa dan melahirkan citra positif bagi semua kalangan.

\section{SIMPULAN DAN SARAN}

\section{A. Simpulan}

Hasil analisis terhadap jawaban responden menunjukkan bahwa persepsi mahasiswa terhadapat pembelajaran bahasa Arab secara umum masuk dalam kategori rendah. Keistimewaan dan prospek yang menjanjikan untuk dunia kerja, termasuk dalam jajaran mata kuliah yang bergengsi tidak mampu menghasilkan persepsi yang tinggi karena minimnya sarana prasaran, kurangnya motivasi dan minat belajar serta stigma bahwa bahasa Arab sulit sekali dipelajari. Rendahnya persepsi mahasiswa berimplikasi pada rendahnya kompetensi berbahasa mahasiswa di bidang bahasa Arab. Oleh karena itu motivasi intrinsik dan dukungan ekstrinsik sangat diperlukan dan dibutuhkan untuk meningkatkan persepsi mahasiswa sehingga dapat mendongkrak kompetensi berbahasa mahasiswa

\section{B. Saran}

Perhatian serta dukungan kebijakan yang komprehensif dari pengambil kebijakan di kampus sangat diperlukan, begitupula tersedianya bi'ah 'arabiyah (lingkungan yang bernuansa Arab) serta dukungan fasilitas sarana dan prasarana yang memadai. Selain itu kreatifitas dan penerapan metode dan strategi pembelajaran yang variatif oleh dosen pengampu selama proses pembelajaran diharapkan mampu meningkatkan persepsi dan kompetensi bahasa Arab mahasiswa.

\section{DAFTAR RUJUKAN}

Arsyad, Azhar,(2010). Bahasa Arab dan Metode Pengajarannya. Yogyakarta: Pustaka Pelajar.

Azra, Azumardi. (2007). Jaringan Ulama Timur Tengah Abad XVII Dan XVIII . Bandung: Mizan.

Fika, Megawati. (2016). Kesulitan Mahasiswa dalam Mencapai Pembelajaran Bahasa Inggris Secara Efektif, 5 (2), 147-156.

Hadi, Syamsul. (1995). Bahasa Arab dan Khazanah Sastra Keagamaan di Indonesia, Jurnal Humaniora Vo. 26, No.2.

Nasaruddin. (2018). Responsbiliti Kurikulum Pendidikan Bahasa Arab terhadap Wisata Syariah di Lombok-NTB, Proceeding The 1st International Conference on Halal Tourism, Products, and Services. XII, 146152.

Rodjinandari, Nanny dan Bambang Supriadi. (2016). Kompetensi Pendamping Pemandu Wisata Local sebagai Developers of People, Jurnal Pesona, Vol. 2, No. 12.

Sauri, S. (2020). Sejarah Perkembangan Bahasa Arab dan Lembaga Islam di Indonesia. INSANCITA: Journal of Islamic Studies in Indonesia and Southeast Asia, Vol. 5, 73-88.

Slameto. (2010). Belajar dan Faktor-Faktor yang Mempengaruhinya. Jakarta: Rineka Cipta.

Suharman. (2005). Psikologi Kognitif. Surabaya : Srikandi.

Tohe, A. (2018). Arabic Language at The Crossroad: A Case Study in Indonesia. Prosiding Pertemuan Ilmiah Internasional Bahasa Arab (PINBA) XI, 977-988.

Ridlo, Ubaid. (2015). Bahasa Arab dalam Pusaran Arus Globalisasi: Antara Pesimisme dan Optimisme. Jurnal Ihya'ul 'Arabiyyah. Vol. 1, No. 2.

Sobur, Alex. (2003). Psikologi Umum. Bandung : Pustaka Setia.

Walgito, Bimo. (1990). Psikologi Sosial. Yogyakarta: Andi Offset. 